\title{
Aby Warburg: \\ El arte como política de la vida
}

\section{Hernán Ulm}

Universidad Nacional de Salta, Argentina

Recibido el 5 de mayo de 2019; aceptado el 7 de julio de 2019

\begin{abstract}
Resumen
Este artículo intenta un abordaje integral de la obra de Warburg para mostrar que, más allá de las contrariedades que forman parte de la Historia del Arte, la propuesta del investigador alemán, dirigida a la elaboración de una "memoria de las imágenes", tiene por objetivo final construir una definición de arte entendida como "política de la vida". El artículo quiere mostrar de este modo que el pensamiento warburguiano adquiere su relevancia actual en la medida en que ofrece elementos para pensar los devenires contemporáneos alrededor de las imágenes. Si el presente es un "combate" de imágenes, la iconología presenta una heurística que nos permite comprender los sentidos y posibilidades inscriptas en tal combate.
\end{abstract}

\section{Aby Warburg: Art as a politics of life}

\begin{abstract}
This article attempts an integral approach to Warburg's work to show that, beyond the setbacks that are part of the History of Art, the proposal of the German researcher, aimed at the development of a "memory of images", ensures a definition of art understood as "politics of life". The article claims to show that warburguian thought acquires its current relevance insofar as it offers elements to think contemporary becoming around images. If the present is a "combat" of images, iconology presents a heuristic that allows us to understand the senses and possibilities inscribed in such combat.
\end{abstract}

Palabras clave

Arte

Memoria

Tiempo Imágenes Política

Ella tenía los ojos fijos en un lugar del espacio y allí vería desenroscarse el poema (...). De pronto, en medio de uno de los poemas, ella empezó a dar largos pasos de un lado para otro (...). Sus pasos eran un acontecimiento extraño, no solo por el hecho de caminar así en medio de un poema, sino porque ponía en movimiento dimensiones y volúmenes desacostumbrados. En el paño encorpado de aquel vestido se veía ondular un oleaje color vino; y 
1. En español disponemos de varias compilaciones en las que se presenta el amplio abanico en torno a las cuestiones de las imágenes, entre otras Cfr. García Varas (2011), Brea (2005). Una crítica a la ontología del arte y de las imágenes es particularmente trabajada por Bal (2016). esas ondas eran lentas, aun en los instantes en que de pronto subía la marea y sorprendía la rotación de aquellos grandes volúmenes (...). Aunque en aquellos momentos yo hubiera olvidado las palabras y las fechas de la historia, es posible que ellas intervinieran en los sentimientos que yo debía formarme de aquella época (...). Hice todo lo que pude por acercarme a la vida de aquellas figuras y allí encontré por primera vez las raras proporciones y los pasos de costado. Ahora, mientras yo miraba a la recitadora, aquellas figuras me habían devuelto la visita (...). Ahora la recitadora había tomado esas mismas líneas y las había llevado con toda la realidad que encarnaba el presente: los espacios blancos que antes yacían en el cuerpo de las diosas, ahora habían sido cargados con este encorpado vestido color de vino, que forma la resistencia y la elasticidad de los contornos. (Hernández, 2015: 268-9)

\section{El arte más allá de todas sus muertes}

A lo largo del tiempo, el arte ha muerto demasiadas veces como para tomarnos ahora el derecho de elaborar una nueva nota de su necrológica: lo ha hecho una vez con Plinio, ha renacido para mejor morir con Vasari, se ha recuperado con Winckelman para desfallecer luego en la mano de Hegel. La Historia del Arte parece tener que establecer las condiciones de su muerte (la del arte y la de la historia que lo cuenta) y de su renacimiento (del arte y de la historia que lo cuenta) para luego volver a esgrimir la astucia de un asesinato que no cesa de regresar (del arte y de la historia que lo cuenta).

Es sabido que desde Walter Benjamin no se trata de anunciar su muerte, sino de encontrar una definición de arte que, ante las condiciones exigidas por la emergencia de los nuevos técnicos de reproducción de imágenes, funcione como parte de una estrategia para apropiarnos de una práctica cultural que por siglos (pero al fin y al cabo no tantos, sólo desde fines del XVI y hasta mediados del XIX aproximadamente) definió la experiencia burguesa de la vida expresada en la separación y relativa autonomía del arte y la política. En la misma dirección, desde el último tercio del siglo pasado, como lo muestran autores y autoras que forman parte del campo de los estudios visuales, por un lado (Mieke Bal, Keith Moxey, José Luis Brea, W.J.T. Mitchell) tanto como por otro lo hacen los teóricos de la llamada "ciencia crítica de la imagen" (Horst Bredekamp, Hans Belting, Gottfried Boehm), se trata de establecer las condiciones en que esta práctica puede ser recortada y pensada en las múltiples fragmentaciones que tienen lugar desde el siglo XIX y que no hace sino multiplicarse en la experiencia de la producción digital que traza la cartografía de nuestro presente (Brea, 2010). En este sentido la tarea que nos cabe no consiste ya en declarar la muerte del arte (para mejor contar su pasado) sino en diagnosticar el ocaso de una época en que cierta forma de definir el arte tuvo su apogeo.

Por ello decir que el arte (ya) no existe resultaría inútil y desproporcionado. Allí están las obras que nos llegan desde el pasado (las pinturas, las esculturas, los grabados, las partituras, los edificios) desplegándose y acumulando su presencia en el tiempo. Allí también están los nombres de los "autores", las marcas de su "estilo", los argumentos de sus "formas". Y aquí están, también, las performances, las intervenciones, las instalaciones y las prácticas digitales (dentro y fuera de los museos y de las galerías, poniendo en duda la separación entre público y privado) exigiendo al pensamiento la necesidad de volver a pensar en el arte (ahora que no precisa definirse por su separación sino por su imbricación con otras "esferas" de la vida), imponiendo la urgencia de pensar con el arte (que, lo sabemos desde Kant, es aquello que da "mucho que pensar"). 
En síntesis, no se trata -como una marca de la indigencia de nuestro tiempo- de volver a decretar la muerte de aquello que, sin embargo, tiene una "vida póstuma", una "insistencia", una "persistencia", una "sobrevivencia", un Nachleben, sino de liberar en la práctica que seguimos llamando "arte" una dimensión que lo presente como el síntoma por el cual se expresan las fuerzas que constituyen y configuran la cultura. Siendo sumamente breve, diré que intento mostrar que no siendo "una cuestión de gusto", el arte es un modo de pensar una política de la vida. O para decirlo de un modo que todo se lo debe a Nietzsche, una vez que el arte no puede ser pensado a partir de la noción de gusto, cabe preguntarnos por la utilidad o el perjuicio del arte para la vida.

\section{La aventura nómade}

Yo desconfío de todos los sistemáticos y me aparto de su camino. La voluntad de sistema es una falta de honestidad. (Nietzsche, 1979: 33)

Es desde esa inquietud por pensar el arte sin su muerte, de pensar el arte en su relación con la vida que la obra de Warburg (1866-1929) vuelve a nosotros, lectores que él no esperaba, para retomar (en esa experiencia de escritura que lleva su nombre) las preguntas que no cesan, a partir de él y desde entonces, de multiplicarse. Realizar la tarea de definir el arte "más allá de todas sus muertes" es lo que el pensador alemán nos proponía y a lo que nos invita en la diáspora de sus textos. ${ }^{2}$ En este sentido, Warburg es el nombre de un despliegue que en vano quisiéramos reducir a una unidad de significado, constituyéndose como símbolo de una dispersión. ${ }^{3}$ Por eso los "warburguianismos" - del neokantiano de Panofsky al nietzscheano de Didi Huberman, del antropológico de Carlo Severi al indiciario de Ginzburg- no cesan dar vueltas en torno de una herencia que, como decía René Char, "no ha dejado testamentos". 4 "Interpretar" los escritos warburguianos es, antes que otra cosa, apropiarnos de ellos y ponerlos a funcionar según reglas que constituyen, cada vez, un rostro distinto, una cartografía diferente que no se puede reducir a la unidad (Warburg no cesó de inventar cada vez nuevas reglas para tratar de producir una epistemología transdisciplinar que no reconociera en las convenciones académicas el límite de su nomadismo): no hay "libro" en el que un "método" warburguiano se exponga (a diferencia de sus antecesores y de sus sucesores, Warburg no escribe ningún discurso del método sino que anota los movimientos de sus derivas). El carácter fragmentario de su pensamiento -desdoblándose y replegándose en artículos, conferencias e intervenciones y materializándose en su Biblioteca y en el Atlas Mnemosyne- resulta el sello más notable de un trabajo que quiere inventarse su propio objeto y que, creando nuevos recorridos, se borra en las trazas de aquello que él mismo ha querido escribir (los textos que ha escrito muestran las derivas de un pensamiento que se arroja a sus conflictos: son, si se quiere, "diarios de guerra" en los que se deja constancia de la batalla implacable que el pensamiento warburguiano lleva adelante contra Warburg). Basta poner el énfasis en una inflexión, basta tomar los textos desde una perspectiva diferente, basta recortar de otro modo la lectura para que unos Warburgs se desarmen y dejen aparecer otros Warburgs formando nuevas constelaciones. Al fin y al cabo así pensaba él mismo la organización de su Biblioteca; y así también realizaba su Atlas, hecho en el trasfondo de la noche de la que emergían las imágenes como estrellas para orientar un pensamiento siempre abierto a la experiencia de su pérdida: Warburg es una constelación y, como ellas, está rodeado por la negra oscuridad de lo que no se da a ver. ${ }^{5}$ Warburg es el efecto de sentido de lo que en él se quiere pensar.
2. Pese a que en su obra no encontremos referencias explícitas a los movimientos artísticos que se despliegan entre fines del siglo XIX y principios del siglo XX, no es imposible pensar que la explosión de la disciplina que Warburg propone en 1912 es solidaria de la explosión que los y las artistas promueven en la cultura burguesa (Duchamp hace estallar la disciplina Arte, los dadaístas transgreden las fronteras de los géneros; los surrealistas transfieren a la creación artística las pulsiones del inconsciente).

3. En su estudio integral sobre la obra de Warburg, Didi Huberman muestra cómo el pensamiento del teórico alemán se comprende a través de la elaboración de una noción de símbolo no dialéctico ni unificante. El símbolo en Warburg permite pensar la cultura no como la identidad de los contrarios sino como expresión de conflictos y de tensiones. Por eso el símbolo es el lugar en el que el "espacio del pensamiento" tiene lugar. Por su lado, Carlo Severi muestra la constelación que, en Warburg, abre el juego de desplazamientos y transformaciones por las que la noción de símbolo no remite al régimen de la identidad sino a la economía de la diferenciación.

4. "Notre héritage n'est précédé d'aucun testament". El aforismo de Char se encuentra en Feuilleits d'Hypnos y ha sido largamente comentado por Hannah Arendt (2003)
5. Recordemos que el Atlas es un conjunto de imágenes sujetadas sobre paneles negros formando constelaciones de relaciones que, una vez fotografiadas, podían ser dispuestas en otra configuración. 


\section{La(s) memoria(s) de las imágenes: el trabajo de la anamorfosis}

Si interpretar fuese aclarar lentamente una significación oculta en el origen, sólo la metafísica podría interpretar el devenir de la humanidad. Pero si interpretar es apoderarse, mediante violencia o subrepticiamente, de un sistema de reglas que no tiene en sí mismo significación esencial, e imponerle una dirección, plegarlo a una voluntad, hacerlo entrar en otro juego, y someterlo a reglas segundas, entonces el devenir de la humanidad es una serie de interpretaciones. (Foucault, 1992: 19)

Es por esta razón que su trabajo, lejos de constituirse como una "ciencia sin nombre" (según lo afirma Agamben), multiplicó los esfuerzos por darle uno. Tal vez, en primera instancia, porque el arte no fuera para él "objeto" de una "ciencia", sino el "efecto" de una "interpretación" (en el sentido que Foucault encontraría en sus lecturas de Nietzsche): para Warburg no hay "Arte" sino un conjunto de prácticas (discursivas y no discursivas) que instituyen un cierto orden en el cual el "arte" emerge como un objeto de interés cultural (no se trataría, así, de preguntar qué es el arte sino bajo qué condiciones el arte puede retornar). Esta posición (esta toma de posición contra las nociones de gusto en las que la cuestión del Arte estaba encerrada) le ha permitido a Warburg moverse con elasticidad desde las obras de Botticelli a los almanaques meteorológicos de la Alemania Medieval; o encontrar rastros de la Antigüedad migrando desde los dioses olímpicos a los demonios astrales para llegar bajo la forma de una figura extraña en los frescos del Palacio Schifanoia; o, en fin, encontrar en El desayuno sobre la hierba (1863) la persistente presencia de los dioses paganos que anunciaban, en el lateral de un sarcófago antiguo, el inicio de una batalla que definiría la historia occidental. En esas aventuras Warburg se propondrá producir, sea una "ciencia crítica de la cultura", sea una "psicología de las expresiones humanas", sea una "sismografía de la cultura", sea una "iconología del intervalo" (y podríamos continuar sumando títulos para un desafío que todavía espera su porvenir): lo que cada una de estas enunciaciones intenta no es apresar un objeto que les sería dado sino construir un tema a partir del cual configurar las leyes de producción de sentido por el cual la cultura se tensiona, se desborda, se transgrede como condición misma de lo que aparece bajo los ropajes diferentes y diferidos de lo que no cesa de repetirse al modo trágico. Porque entre los dioses olímpicos y su forma de inscribirse en el Palacio Schifanoia, no son los mismos sentidos los que configuran la constelación. Entre el terror de los demonios que observan el comienzo de la guerra de Troya y los plácidos burgueses -que arrojados a su almuerzo campestre se olvidan de sí-, no es la misma energía la que se libera en las imágenes: un juego de intensificaciones, polarizaciones e inversiones recorre y atraviesa estas migraciones modificando, alterando y produciendo sentidos que no se dejan traducir de una época para otra, como no se dejan, tampoco, traducir ni comprender por la remisión de la imagen para el texto (el trabajo warburguiano trata, desde la tesis doctoral dedicada a la obra de Sandro Botticelli, de pensar las distancias que se abren entre las imágenes y entre las imágenes y los textos, porque ¿qué necesidad tendríamos de duplicar en las imágenes aquello que ya fue dicho en los textos sino porque entre ellos se presenta algo que ni se deja nombrar ni se da enteramente a ver?). No es pues una cuestión de estilos (que volverían pendularmente) ni de recepción (que haría a una época más sensible a ciertas determinaciones del gusto que otra) sino de la elaboración de un conflicto que no tienen en el lenguaje un modo de expresión y, por ello, atraviesa como un síntoma las unidades supuestas de la época y de la cultura.

Es, también, un modo de pensar la temporalidad no histórica que se inscribe en las imágenes, reflexión que interroga las configuraciones de un tiempo que no se deja reducir a la escritura y permite pensar una pulsión que no se deja apresar en las oposiciones estructurales del signo. Imágenes y textos abren también el espacio que 
distancia el tiempo histórico del tiempo como memoria: nuevamente la abertura, la distancia como condición del pensar. Estamos siempre entre dos tiempos que no se dejan traducir, que no se dejan comprender uno por el otro sino que, en lo que en ellos no se deja reducir, se instala aquello que nos obliga a pensar (siempre, decía Deleuze, pensamos bajo el imperio de una violencia). Porque, ya se habrá notado, poco queda de la Historia del Arte en el trabajo de producción warburguiana. Se trata, contra la tradición inaugurada por Vasari que quería que la escritura las salve del olvido, de construir una memoria de las imágenes que establezca la economía de su persistencia. Contra la suave continuidad que establecía las relaciones entre las obras, los autores, los estilos y las épocas en una línea infinita de progreso realizando su idealidad, Warburg descubrirá circulando entre las imágenes un tiempo discontinuo, violento, quebrado, que hace emerger las imágenes del pasado en un presente que no las sabía esperar. Warburg descubre que la memoria no cesa de reinventarse el pasado que constituye el suelo agrietado del presente (lo que habilita, como lo hacen Didi Huberman y Michaud a pensar en el montaje como operador heurístico de la iconología warburguiana). En este sentido el pasado no es lo que pasó, no es lo que ha pasado, sino lo que (nos) pasa, lo que (nos) está pasando inscribiéndose como duración en las imágenes. ${ }^{6}$ Una vez que abandonamos la pretensión colonizadora de la Historia (y de la escritura como modo único de contar el tiempo), aparecen las memorias actuando en las imágenes (tal vez por ello, las perspectivas decoloniales pueden encontrar en los textos de Warburg una alianza que se renueva y esto en un doble sentido: por una parte, recusando el sentido único de la Historia como modo de hacer lugar a lo que puede y debe ser contado y, por el otro, mostrando que no es en la escritura, no es en los textos sino en las imágenes en donde las subalternidades hacen el ejercicio sobreviviente de sus resistencias). ${ }^{7} \mathrm{El}$ tiempo que se va desplegando en su Atlas es el resultado de la anamorfosis de la memoria que atraviesa las imágenes modificándose en el impacto con el presente. Lo que se recuerda en ellas no es la verdad de los hechos sino la pregnancia del sentido. La memoria no es, en este caso, ni verdadera ni falsa, sino ficcional: a través de lo que en ellas retorna no veremos la forma de un original que se nos daría en la pureza de su aparecer sino la figura siempre distorsionada de un tiempo pretérito que ha sido interpelado por la urgencia de nuestro presente. Por ello, no se trata de buscar, detrás de las imágenes, la palabra que asegure su significado, o la arqui-imagen que reproduciéndose indefinidamente a sí misma ofrecería la auténtica presencia de aquello que se da sin repetición: lo que retorna, trágicamente, siempre se anuncia como diferencia. Por ello Warburg no se propone decirnos qué es una imagen sino establecer las condiciones trágicas que en ellas se elaboran. Y así, la tarea que se impone es perseguir las múltiples desviaciones y las fragmentarias dispersiones por las que algunas imágenes se reactualizan contaminándose en las migraciones de las que son portadoras haciendo vibrar el suelo del presente en el que vuelven a aparecer. ${ }^{8}$ Se trata, como diría más tarde Barthes leyendo a Nietzsche, de construir una "diaforalogía", ciencia de las pequeñas diferencias que en las imágenes deciden el sentido de lo que aparece (el artículo de 1912 sobre el Palacio Schifanoia, o el texto sobre El desayuno en la hierba hacen de este ejercicio de producción de la pequeña diferencia su heurística principal).

\section{Curarnos por las imágenes}

La lucidez es la herida más cercana del sol

(René Char, 2002: 124).

Resumiendo, Aby Warburg expuso a lo largo de sus múltiples artículos las contradicciones, violencias e inutilidades que la Historia del Arte, concebida como mera disciplina académica, traía consigo. Tal disciplina consistía en identificar patrones
6. La cuestión del tiempo no histórico es un tópico retomado de maneras diversas por Nietzsche, Bergson, Warburg, Freud, entre otros. Esta duplicidad del tiempo y de las técnicas que lo elaboran (la escritura para la Historia, las imágenes para la Memoria) ha sido objeto del estudio de Flusser y Kittler entre otros.

7. Al respecto se puede consultar la compilación ya indicada más arriba de José Luis Brea (y, particularmente el artículo de Ana María Guasch), 2005; Bal, 2016; Moxey, 2015.

8. En 1938 Artaud escribirá El teatro y su doble, en el cual el concepto de contaminación será también clave para la comprensión de la cultura. 
9. El caso de Panofsky es particularmente importante en la reconversión de la iconología como ciencia en el siglo XX. Su "método iconológico" fue un modo de hacer volver (de devolver) la Historia del Arte a los principios "académicos" de su fundación. La exposición del método panofskyano se encuentra en su Estudios de iconología. Una crítica a este movimiento panofskyano se puede encontrar en el libro de Didi Huberman, Avant l'image (1990). universales del gusto y luego encontrarlos "encarnados" con mayor e menor grado de perfección en las diversas épocas en las que el Arte se desplegaba como una evidencia de la Cultura. Para ello se debían señalar y mostrar las continuidades entre formas y estilos que daban sentido, en la obra y a partir de ella, a las diversas configuraciones que justificaban una Época (en una zaga que se extiende de Vasari y Winckelmann a Wölfflin y, luego de Warburg, pasaría por Panofsky y Gombrich ${ }^{9}$ ). Para Warburg, ese modo academicista de consolidación disciplinar resultaba intolerable. Así lo expone en las notas preparatorias de su conferencia El ritual de la serpiente, pronunciada en ocasión de su internación en Kreuzlingen, en el psiquiátrico de Bellevue, al cuidado de Ludwig Biswanger. Allí tematizaba la necesidad de abandonar las categorías tradicionales de arte para pensarlo según una orientación que la alejara tanto de las discusiones estilístico-formales del historicismo del siglo XIX como de las disputas esteticistas heredadas de la modernidad. Al fin y al cabo, esas discusiones no sólo son estériles (es decir incapaces de engendrar vida) sino también asqueantes. Es en ese rechazo que se fundarían los principios de una iconología que no está ya atenta a las cuestiones del gusto sino a las fuerzas vitales que animan el juego incesante por el que retornan las imágenes.

¿Por qué fui? ¿Qué me atrajo? Desde afuera, en la superficie de mi consciencia, diría que, como yo experimentaba tal repugnancia hacia el vacío de la civilización del Este de Norteamérica, decidí huir hacia las cosas reales y hacia el saber, a la aventura (...). Además estaba asqueado de la historia del arte estetizante. La contemplación formal de la imagen, no considerada como un producto biológicamente necesario entre la práctica religiosa y artística (cosa que comprendí recién más adelante) me parecía que daba lugar a parloteos tan estériles que después de mi viaje a Berlín, durante el verano de 1896, traté de volver a mis estudios de medicina (Warburg cit. en Michaud, 2018: 213).

Podemos adivinar el destino de la iconología tal como parece indicarse en este pasaje: en primer lugar, un desplazamiento desde "la obra de arte" a la imagen; al fin y al cabo, si las despojamos de toda valoración estética, las obras se aparecen como elementos de una configuración visual: pero en tanto elementos resultantes de una configuración visual, como lo señala Severi, las imágenes son el resultado de un combate por hacerse un mundo visible. Las imágenes son por ello portadoras de una carga energética que las atraviesa y que establecen su condición: de un lado las fuerzas del caos que no cesa de amenazar la existencia de aquel que llegará a ser hombre y del otro las de ese existente que exige de las imágenes como mediación imprescindible para constituirse como hombre. En segundo lugar, ese desplazamiento permite que comprendamos las imágenes como un "producto biológicamente necesario" (Severi, 2010): las imágenes son huellas mnémicas de aquel combate y se encuentran allí disponibles como herramientas para la batalla de nuestra existencia (la ausencia de imágenes, la ausencia de las imágenes que Warburg llamará arte, conducirá a la cultura a su desaparición en la agonía de la tecnocracia o en la agonía de la teocracia). El arte es la imagen en la que persiste, en la que insiste, en la que tiene vida póstuma la contradicción de fuerzas que no se dejan superar porque, al modo en que Nietzsche pensó la tragedia no se trata de que una de las fuerzas niegue a la otra sino de que ambas fuerzas dicen, al mismo tiempo y simultáneamente SÍ. Y este desplazamiento destina el arte (lo que sea que el arte sea) a una cura: cura de sí mismo, cura del existente y cura de la cultura. El arte será al fin de cuentas (eso es lo que quisiera establecer) un modo de curar a la cultura de las condiciones enfermizas que lo circunscriben a las formas edulcoradas del decorado o a los modos degradados de la Ilustración: para que quede claro, las imágenes que llamamos artes, no ilustran ni se comprenden, en todo caso no se agotan, en su remisión a las fuentes textuales que actuarían sobre ellas tutelarmente como la autoridad frente a sus subordinados: desde su tesis doctoral Warburg irá persiguiendo ese efecto de distanciamiento que se llama Denkraum. Como resultado 
de esta doble operación y siguiendo el movimiento de este dislocamiento, más que preguntarnos qué es el arte, podemos dar lugar a otro modo del preguntar (tal vez ahí la importancia de los textos warburguianos consista en el modo que tienen de inventarse un problema que ya no es aquel por el que en vano buscábamos una respuesta). Creo poder leer algo de esta inquietud en la presentación general al Atlas que Warburg realizara en 1929:

El acto de interponer una distancia entre uno mismo y el mundo exterior puede calificarse de acto fundacional de la civilización humana; cuando este espacio interpuesto se convierte en sustrato de la creación artística, se cumplen las condiciones necesarias para que la conciencia de la distancia pueda devenir en una función social duradera -que el ritmo de puesta en vibración de la materia y el reposo de la misma en la sofrosyne presenta como un ciclo entre la cosmológica de las imágenes y la de los signos-, la suficiencia o el fracaso de la cual como instrumento espiritual orientador determina el destino de la cultura humana. Al hombre que como artista se debate entre las concepciones religiosa y matemática del mundo viene a ayudarle de forma característica la memoria tanto de la personalidad colectiva como la del individuo: no creando sin más un espacio para el pensamiento, pero sí fortaleciendo en los polos extremos del comportamiento psíquico la tendencia a la contemplación serena o a la entrega orgiástica (2010: 3).

Si me he querido extender en la cita es porque "más allá del gusto" el arte se nos presenta como una cuestión de vida, de supervivencia (de Nachleben, de Denkraum, de la conversión de la imagen en Pathosforlmen, para decirlo en alemán y dejar a la intemperie las etimologías posibles de estas palabras clave de las dispersiones warburguianas). El arte se presenta (al final de la producción de Warburg) como una cuestión del frágil equilibrio por el que la existencia se tiende sobre el precipicio de sus angustias y se mantiene en la tensión que abre la polaridad de la religión (o de la magia, o de Dionisos, o del pathos) y de la ciencia (o de la técnica, o de Apolo, o del ethos). El arte, para continuar en la constelación nietzscheana, se presenta para Warburg como esa cuerda que se tensa y que es la tensión misma de una posible caída:

El hombre es una cuerda tendida entre el animal y el superhombre, -una cuerda sobre un abismo. Un peligroso pasar al otro lado, un peligroso caminar, un peligroso mirar atrás, un peligroso estremecerse y pararse. La grandeza del hombre está en ser un puente y no una meta: lo que en el hombre se puede amar es que es un tránsito y un ocaso (Nietzsche, 1983: 36).

Esa cuerda por la cual, ya en el final del parágrafo 1 de El nacimiento de la tragedia, Nietzsche exigía que la propia existencia se concibiera como obra de arte: "El ser humano no es ya un artista: se ha convertido en una obra de arte" (Nietzsche, 1994: 45).

El arte como interpretación de la vida. La vida como interpretación artística. Hay, inscripta en el arte (en las imágenes que llamamos arte), una política de la vida. Ese destino es el que abre las investigaciones warburguianas y el que quiero recorrer muy brevemente para pensar desde aquí su actualidad.

\section{Los indios Hopi como renacentistas}

Ahora bien, escrito en 1923, El ritual de la serpiente resulta ser una memoria del viaje que Warburg realizara al sur de los Estados Unidos inmediatamente después de la presentación de su tesis doctoral (en la que analizaba las obras de Botticelli, El nacimiento de Venus y La primavera). Atendiendo a la importancia que el propio Warburg 
le asigna a ese viaje, cabe preguntarnos cuándo comienza la tarea warburguiana por la que, alejándose del academicismo decimonónico, se propone reinstituir un nuevo sentido inaugural a la disciplina y cómo afecta esto a la visión del arte que surge de los artículos y conferencias que escribe desde entonces. ¿Comienza en su tesis doctoral en la cual se aproxima a una primera versión de la figura de las ninfas cuyo modelo le servirá para pensar la polaridad de las imágenes?, ¿o comienza más bien en el viaje de "purificación" al sur de los Estados Unidos por el cual se quiso liberar del academicismo?, ¿o en la redacción de la memoria de ese viaje escrita casi 30 años después?, ¿ con el cual su trabajo parece encontrar un primer concepto general?, ¿en 1912 cuando revela un misterio iconográfico, "como si fuera un film" y llama a una ruptura radical con las fronteras disciplinares de su ciencia? En todo caso, como señala Michaud, la pregnancia de las tesis expuestas en El ritual de la serpiente parecen acompañar sino todos, buena parte de los textos warburguianos posteriores a su viaje. Para probarlo, Michaud muestra la curiosa relación que Warburg mantiene con las escaleras en dos momentos centrales de sus investigaciones: uno, en el texto de la conferencia; el segundo, en el análisis que realiza de la obra de Doménico Ghirlandaio, en un artículo de 1902 (es decir unos seis años después del viaje pero 21 años antes de la redacción de la conferencia) en el que intenta determinar las condiciones de aparición del arte de retrato en el mundo florentino. El texto de la conferencia afirma:

Para quien quiera representar simbólicamente el devenir y los ascensos y descensos de la naturaleza, el escalón y la escalera encarnan la experiencia primigenia de la humanidad. Son el símbolo de la lucha entre lo alto y lo bajo en el espacio de la misma forma que el círculo -la serpiente enrollada- simboliza el ritmo del tiempo. El ser humano, que ha dejado de caminar en cuatro patas para hacerlo en posición erecta, y que por lo tanto necesita de un instrumento para vencer la fuerza de la gravedad cuando mira hacia arriba, ha inventado la escalera para ennoblecer sus deficiencias con respecto al animal. El hombre, que a la edad de dos años aprende a caminar, percibe la felicidad del escalón porque, como criatura que tiene que aprender a andar, recibe al mismo tiempo la gracia de poder elevar la cabeza. (Warburg, 2004: 25).

Las imágenes de Ghirlandaio que Warburg analiza y a las que hace referencia Michaud parecen acomodarse bien a esta descripción por la que las escaleras se presentan como un tránsito entre dos mundos:

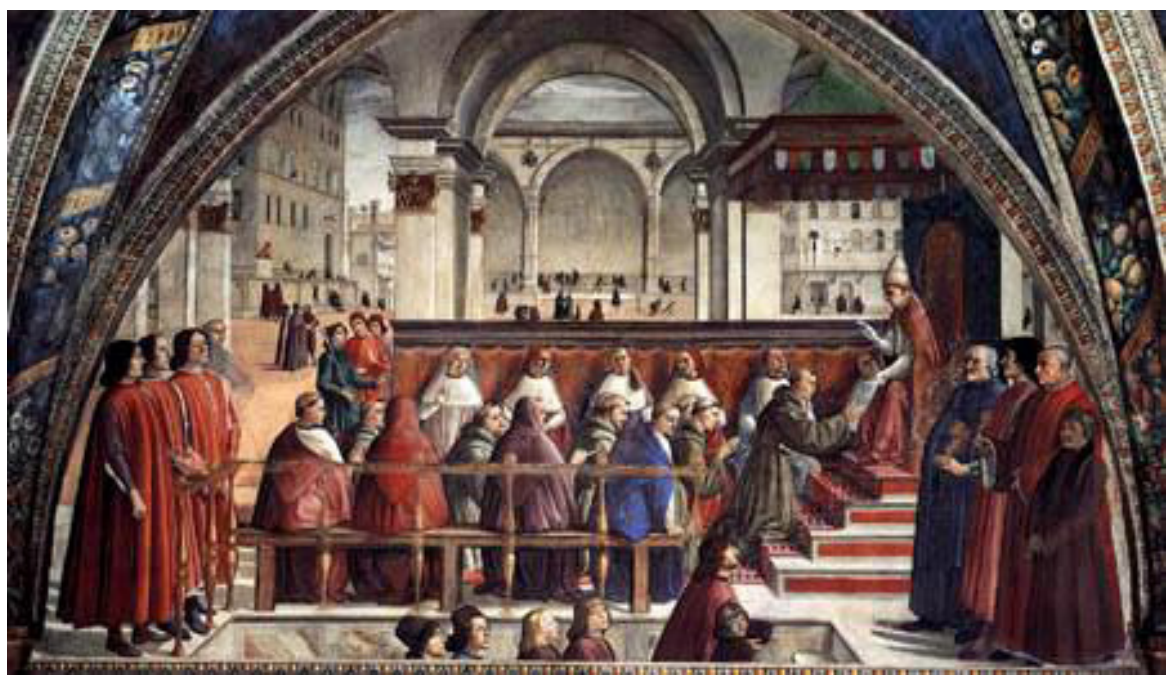




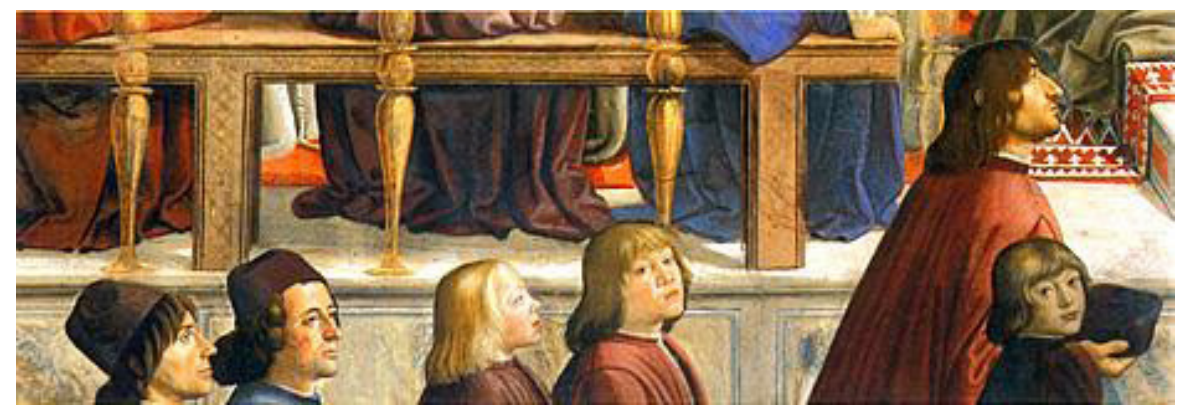

El comentario de Michaud señala las similitudes entre el análisis waburguiano de las escaleras en el mundo Hopi y estas imágenes que resultan centrales en el estudio del nacimiento del género del retrato:

El episodio de Nuevo México debía dejar una huella persistente aunque invisible en la investigación de Warburg: es así como en el estudio del fresco de Ghirlandaio en Santa Trinita, con la escalera que sale de la tierra en primer plano, puede suponerse que Warburg vio un fenómeno de elevación comparable al que se había desarrollado en la iglesia de Isleta con el ascenso del cuerpo del santo fuera de la profundidades del suelo. Pero sólo veintisiete años más tarde, en Kreuzlingen, el viaje vuelve a surgir de manera explícita: este aparece entonces claramente como una nueva etapa en la exploración del primer Renacimiento que Warburg había emprendido desde fines de los años 1880 y que lo llevará del análisis de las obras de Botticelli (1893) al de las obras de Ghirlandaio (1902). La conferencia de 1923 es la recuperación de esa experiencia; en esa fecha, Nuevo México ya no es a los ojos de Warburg solamente un análogo de la Florencia renacentista donde se producen in vivo procesos de figurabilidad, se ha convertido en la metáfora geográfica de su propio pensamiento (Michaud, 2018: 155).

Si se me permite una digresión, a estos momentos quisiera yo agregar otro en el que la escalera invierte su sentido de ascensión (y, en su promesa de caída, intensifica el sentido que la convierte en Pathosformel): la escalera en el final de la película de Lucrecia Martel, La Ciénaga (2001). Allí -la escena es una de las últimas del filme- el hijo menor de una familia pequeño burguesa -luego de ser asolado por el terror al "perro rata"- oye, al otro lado de la tapia que separa su casa de la de los vecinos, el aterrador ladrido del mítico animal. Hay, en el patio, una escalera. Resulta inevitable para el niño subir a ver, a espiar, a satisfacer el deseo de la mirada que calme (que colme) el deseo por conjurar al terrible monstruo. Sin embargo ese deseo será fallido: al llegar casi al borde de la tapia uno de los escalones de la escalera se rompe. El niño cae (lo oímos caer: ni el perro-rata ni la muerte del niño se dan a ver). La "felicidad del escalón" se ha transformado en sentencia de muerte: inversión total del sentido de la escalera y que la convierte en una Pathosformel en sentido estricto.

Pero vuelvo a la idea de Michaud: antes que ser el objeto de una contemplación estética, las imágenes -tanto entre los hombres y mujeres del renacimiento como entre los indios Hopi- parecen cumplir una misma función vital. No se trata, ni en un caso ni en el otro (y seguramente tampoco para nosotros mismos, hoy y aquí), del placer, del goce, por el cual el arte se nos da como la esperanza de una utopía siempre porvenir. Así lo expresa otra de las notas preparatorias:

No sospechaba todavía que como consecuencia de ese viaje a Norteamérica la relación orgánica entre el arte y la religión de los pueblos 'primitivos' se me aparecería tan claramente que vería con mucha nitidez la identidad o más bien la 
10. Esta tesis no aparecerá con tanta fuerza en el texto final de la conferencia. Alli (p. 26-27) parece estar restringida al modo en que nosotros analizaríamos la duplicidad Hopi: "Esta forma social de proveerse de alimentos resulta esquizofrénica: la magia y la técnica se encuentran en el mismo punto. Tal coexistencia de la civilización lógica con una causalidad mágico-fantástica, revela el singular estado de hibridación y transición en el que se encuentran los Pueblo. Ellos no son hombres del todo primitivos, que dependen sólo de sus sentidos, y para los cuales no existe actividad referida al futuro: pero tampoco son como el europeo, que confía su porvenir a la tecnología y a las leyes mecánicas u orgánicas. Los Pueblo viven entre el mundo de la lógica y el de la magia, y su instrumento de orientación es el símbolo. Entre el hombre salvaje y el hombre que piensa, está el hombre de las interconexiones simbólicas. indestructibilidad del hombre primitivo que sigue siendo el mismo en todas las épocas, de manera que podía demostrar que era un órgano tanto de la cultura del Renacimiento florentino como más tarde de la Reforma alemana (Warburg cit. en Michaud, 2018: 213).

Así, las imágenes están para mostrarnos que hay, entre nosotros, restos de un pasado del que no nos hemos podido alejar y que no deja de circundar nuestra existencia. De hecho las imágenes son efectos del temor por el que la existencia es permanentemente amenazada (en el caso de los Hopi, la falta de agua en el desierto, en el caso de los hombres y mujeres del Renacimiento, la falta de un horizonte claro que oriente la vida ante el derrumbe de los sistemas medievales; en el caso de la Reforma, la desazón ante el abismo que se abre en el comienzo del cisma luterano). En todos estos casos las imágenes nos permiten sino dominar al menos sí apaciguar la angustia que nos rodea. En síntesis, construimos imágenes para, a través de ellas, darnos un mundo. Por ello, "hombre primitivo" no designa a un pueblo (más o menos mítico) que se reservaría para sí el origen de la humanidad y designa más bien un "órgano de la cultura" que sobrevive aun en las formas "refinadas" del Renacimiento y la Reforma: algo de los Hopi habita en los Médici y en Lutero (y también ciertamente, en nosotros). No hay evolución, no hay progreso: perviven en nosotros los temores fóbicos que aquejan la existencia. Que sobreviva en esos hombres y mujeres de "cultura refinada", de "pureza civilizatoria" un resto incalculable de la antigüedad más remota: eso basta para que Warburg muestre que ninguna cultura se ha alejado del nacimiento de la humanidad. Para que se muestre que la cultura lejos de cualquier pureza es el espacio de una contaminación que se perpetúa.

Es en ese contexto que Warburg lanzará (ante un selecto grupo de pacientes y sus probablemente azorados médicos -al menos así me gusta imaginármelos) su famosa tesis: la humanidad es eternamente esquizofrénica (lo leo de sus notas preparatorias): $:^{10}$
La humanidad en su conjunto es eterna y en todas épocas esquizofrénica. Sin embargo hay un comportamiento respecto de las imágenes de la memoria que es posible definir ontogenéticamente como anterior y primitivo, pero que sigue siendo secundario. En la etapa siguiente la imagen de la memoria no desencadena un movimiento reflejo inmediato y práctico -ya sea de naturaleza guerrera o religiosa- sino que las imágenes del recuerdo están acumuladas conscientemente en forma de imágenes o signos. Entre esas dos etapas está el tratamiento que recibe la experiencia, y que se puede escribir como una forma de pensamiento simbólico (cit. en Michaud, 2018: 225).

La humanidad está dividida entre un polo mágico y un polo técnico que abre la tensión indispensable para que tenga lugar el "espacio de pensamiento" (Denkraum). A través de las imágenes se elabora un modo de confrontar las angustias fóbicas propias de la existencia. En el cruce entre lo individual y lo colectivo, las imágenes se configuran como huellas mnémicas a las que la humanidad puede acudir cada vez que una situación de riesgo se presenta (y para recordarnos que siempre estamos en esa situación de riesgo mortal).

En resumen, pensar es, antes que otra cosa, construir una imagen a partir de la cual configurarse una existencia posible. Por ello en la medida en que ellas no tienen un significado único, son portadoras de una ambivalencia que les permite reincorporarse a nuevos contextos y cumplir las más diversas funciones. Solo así ellas se transforman en Pathosformel. Solo así ellas sobreviven a la Historia, y tienen esa "vida póstuma", esa fuerza siempre dispuesta a reactualizarse al contacto con el presente que las llama (Nachleben). Sea la ninfa como promesa de amor, ella es también la ménade como 
destino de muerte. Sea la serpiente: ella promete la muerte y la resurrección: la práctica del arte, concebida como acto de interpretación vital, tiene su lugar en objetos y bajo las formas más diversas. Tanto en los rituales que los indios Hopi realizan para ganarse el favor de la lluvia como los frescos con que en Ferrara el Duque de Schifanoia intenta adivinar el destino que lo desampara; tanto en los tapices que los reyes y cortesanos se envían como obsequios de aniversario, como en los pequeños cofres que los enamorados se regalan como señal de su pasión; tanto en los manteles y en la vajillas que acompañan el servicio de la naciente burguesía renacentista como en los almanaques que los campesinos del norte de Europa utilizan como anticipaciones meteorológicas y previsión de las cosechas: las imágenes son medios operativos a través de los cuales orientarnos en el mundo, de vencer nuestros terrores fóbicos y hacer vivible nuestra inevitable tragedia.

\section{El Ángel de Huawei}

No resulta difícil identificar iconográficamente la gigantografía que, con sus casi $5300 m 2$ de extensión, se impone a todas las miradas que transitan frente al Edificio España, al final de la Gran Vía, en Madrid. En la larga lista de ángeles que la tradición cristiana ha pintado, el de la Anunciación es fácilmente reconocible.

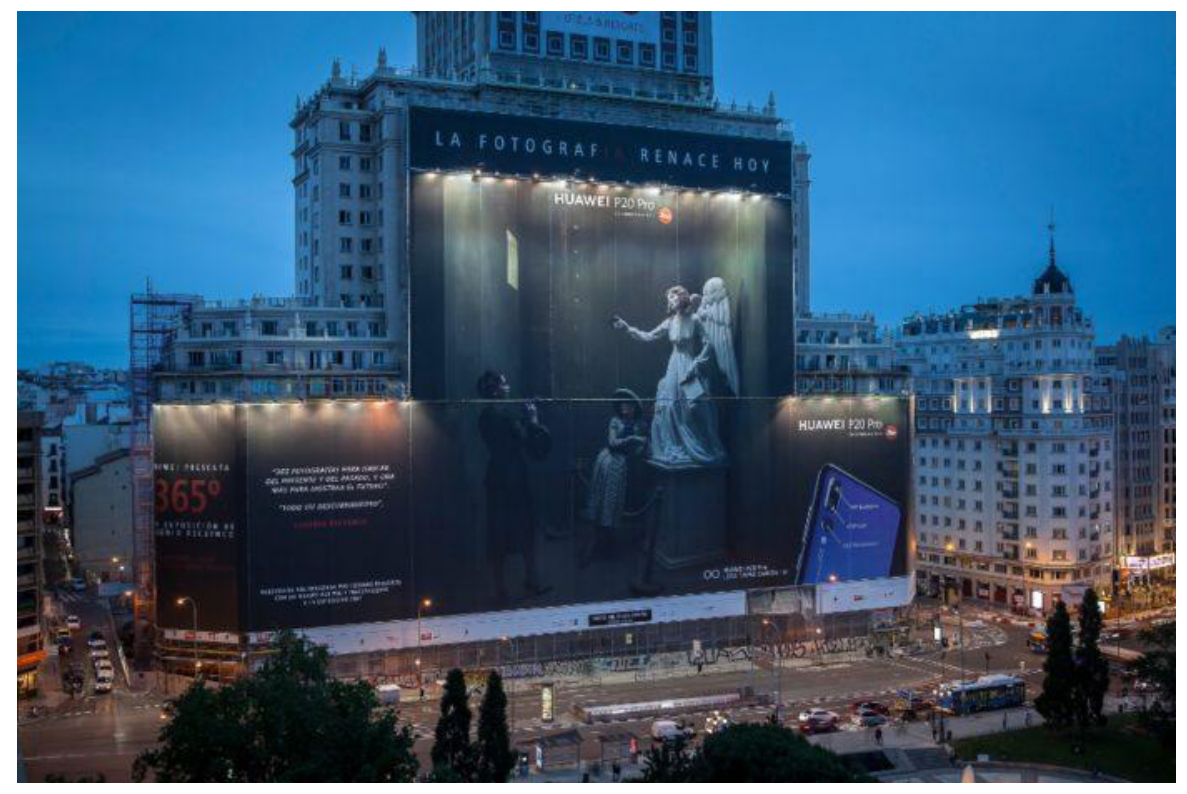

Fuente: https://lapublicidad.net/la-lona-del-huawei-p2o-pro-recibe-el-record-guinness-a-la-mayorvalla-publicitaria/

Baxandall ha identificado diferentes momentos en los que el Renacimiento (prolífico en la producción de Anunciaciones) descompone el anuncio por el que María acepta la palabra de Gabriel; si quisiéramos señalar el instante preciso que la inmensa fotografía viene a presentar, seguramente coincidiríamos que estamos ante la conturbatio (inquietud) que María expresa asombrada ante el saludo del Ángel (Baxandall, 1978). Pero, por si todo esto no alcanzara, y para despejar toda duda, los sitios en que se da cuenta de esta "aparición" lo dicen con toda claridad:

La fotografía 366 está inspirada en los cuadros de la Anunciación del Renacimiento, y artistas como Leonardo da Vinci. La imagen recrea una escena en un museo en la que aparecen dos mujeres, una fotografiando y otra posando, 
junto a un ángel renacentista. El ángel aparece a la vez como fotógrafo y como fotografiado. (Fuente: https://www.reasonwhy.es/actualidad/anunciantes/lamayor-fotografia-del-mundo-hecha-por-un-smartphone-esta-en-madrid-2018-06)

La obra integra la muestra $365^{\circ}$ auspiciada por la empresa de capitales chinos Huawei del artista fotográfico Eugenio Recuenco y, además de ser exhibida en la vía pública puede verse junto con las otras que forman parte de un proyecto artístico en el cual Recuenco trabaja hace años y que reversiona, fotográficamente, momentos de la moda, el arte y la historia que resultan emblemáticos para la configuración colectiva de la memoria occidental.

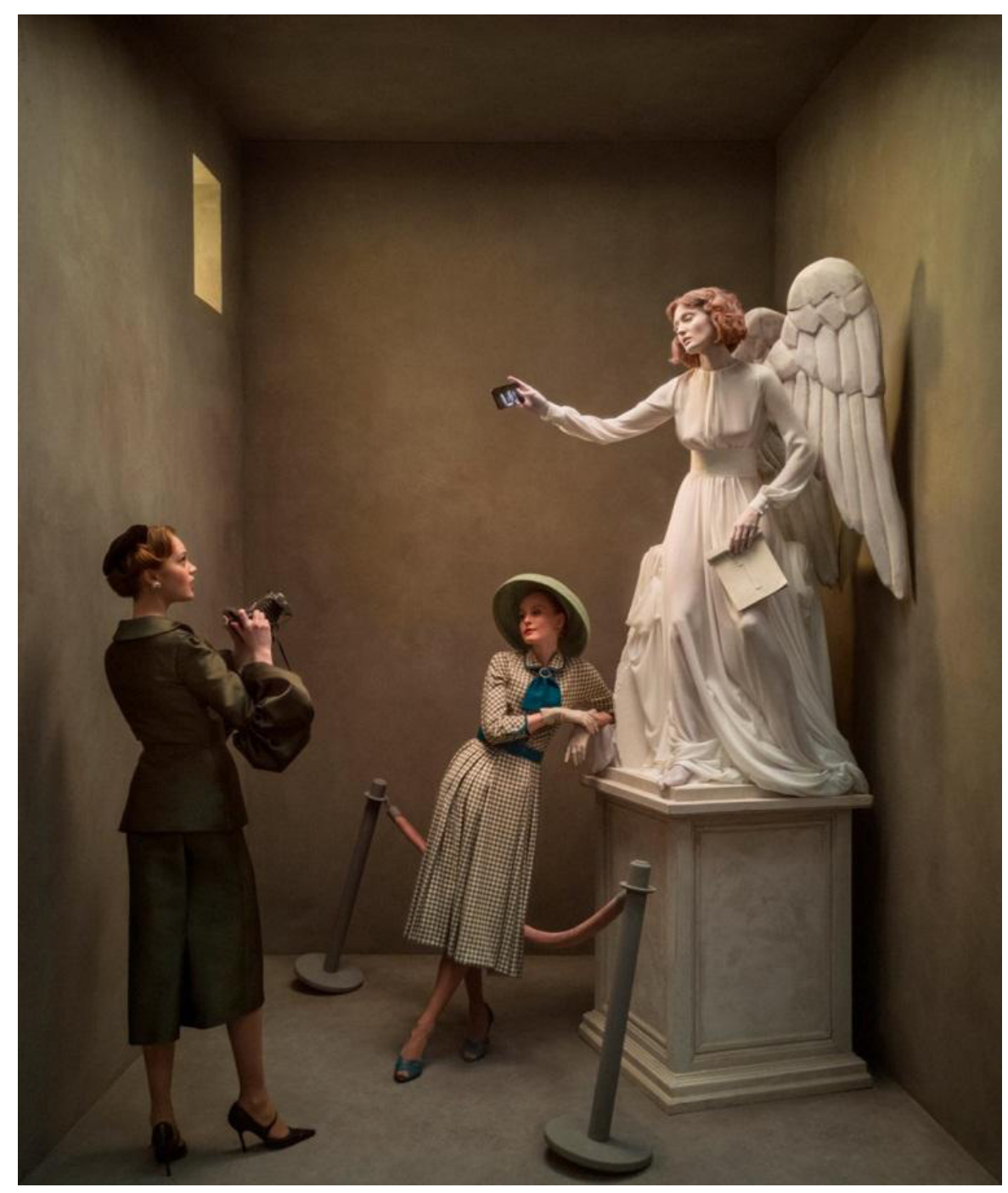

Fuente: https://www.albedomedia.com/cultura/estado-del-arte/eugenio-recuenco-inaugura-su-proyecto-3650-en-el-ceart $/ 11$

En uno de los sitios de presentación se explica que este es:

Un proyecto que ha llevado a Recuenco 6 años de trabajo, y en el que han participado más de 120 modelos y un equipo de 300 personas desde sus inicios en 2010. Ambientadas en los años 50, cada una de estas imágenes tiene un contenido por sí misma, una luz suave muy cuidada que recuerda a la pintura 


\begin{abstract}
barroca —habitual en el trabajo del madrileño-, pero es el conjunto global el que sostiene el discurso sobre el que se basa esta exposición. Su pericia técnica y de cómo su forma de iluminar — que se vale de unas grandes cajas de luz que "encierran" al modelo en un lugar desconectado del espacio/tiempo-consigue ese tono propio en el trabajo de Recuenco. (Fuente: https://www.albedomedia. com/cultura/estado-del-arte/eugenio-recuenco-inaugura-su-proyecto-365oen-el-ceart/)
\end{abstract}

La Anunciación de Recuenco lleva por título 366 (un excedente, un agregado, un día más pero no un día cualquiera sino el día de un anuncio) y no forma parte de un esfuerzo por reinterpretar las palabras del texto sacro sino de la campaña publicitaria mediante la cual se presenta ante los consumidores (esos que somos nosotros, ya no espectadores de obras sino consumidores de imágenes) un nuevo aparato de producción de imágenes. La Anunciación es, sencillamente, un anuncio. El del lanzamiento del nuevo P2o Pro, entre cuyas virtudes se indica la incorporación de una lente Leika que garantiza una calidad de imagen hasta ahora nunca alcanzada por dispositivos digitales anteriores (y que le permite a Huawei mostrarse en la monumentalidad reproductiva).

El propio Recuenco señala las inobjetables ventajas del nuevo aparato:

Hasta ahora las posibilidades que te ofrecían las cámaras de los smartphones para este campo eran muy reducidas. Y esto es lo que ha cambiado. De repente todos llevamos en el bolsillo una tecnología con la podemos crear y conseguir un resultado profesional. Ya no hay límites. (Fuente: http://www. programapublicidad.com/la-mayor-fotografia-del-mundo-huawei-p20-pro-lonagigante-plaza-espana/)

Lo que aquí se anuncia es la imagen como anuncio de algo por llegar: el dispositivo (la foto es exhibida en la fachada del edificio desde la segunda mitad del año 2018; la muestra de Recuenco tendrá lugar a fines de ese año y hasta inicios del 2019). ${ }^{12}$

Esta Anunciación, la Anunciación de Huawei, recurre a algunas formas de distanciamiento de las imágenes renacentistas (pero aun allí, en ese distanciamiento, no cesa de pulsar la necesidad de la promesa, la necesidad de que una espera es posible, de que algo nuevo va a nacer): la primera, más evidente, es un sistema de reemplazos que se produce entre este y aquellos ángeles: el libro (en el que se relata la llegada del Ángel) y los lirios (símbolo de la pureza) han desaparecido de la escena. En su lugar, la mujer sostiene una antigua cámara Leica de los años 50' y el ángel sostiene, en su mano alzada (gesto admonitorio y de saludo), el dispositivo celular y, sujeto bajo su otro brazo, un calendario (que señala la fecha del lanzamiento comercial). Pero aún más: el celular en la mano del ángel no reproduce la imagen de la conturbada fotógrafa (que asombrada, ya no puede apuntar a la modelo que se apoya posando sobre el pedestal donde se yergue el ángel): ante nuestro propio asombro vemos que el ángel se saca una selfie. Más allá de toda interpretación sociopolítica de las selfies como medio de producción de imágenes, el anuncio resulta estremecedoramente claro: la imagen se basta a sí misma frente a aquellos que la consumen. La imagen se produce a sí misma, sin ninguna otra intervención (sin intervención humana); es asexuada, angelical, pura, virginal: las características de la madre de Jesús pasan ahora del lado de la imagen que ya no la reproduce (que solo se reproduce a sí misma). Es el momento puro del nuevo estado de gracia: las dos cámaras enfrentadas anuncian la llegada de una nueva era en que la comunicación ya no precisa de mediadores humanos. Por si faltara algo, el slogan publicitario no hace sino explicitar aun más aquello que aquí se anuncia: en grandes letras, como coronando la imagen, podemos leer "La fotografía renace hoy". En las marquesinas en donde el anuncio se reproduce (tuve oportunidad
12. No es este el lugar (y resultaría demasiado extenso para este artículo), pero mi análisis debería completarse con un estudio de los contratos entre Huawei y Recuenco a los fines de poder establecer con exactitud los términos del encargo y las posibilidades que el fotógrafo ha podido desarrollar para esta imagen dentro de su proyecto general. La heurística warburguiana ha llamado la atención sobre la necesidad de estudiar de modo intensivo las relaciones entre los artistas y sus comitentes a través de análisis de este tipo de contratos. En el mismo sentido vale la pena mencionar que el edificio en el que la foto se exhibió fue objeto de un conflicto de intereses comerciales que dan cuenta de los vaivenes de las políticas culturales en la época de la gubermentalidad neoliberal. El edificio España de Madrid fue objeto de diversas operaciones comerciales por las que diversas empresas de capitales chinos se fueron adueñando de la propiedad. En los sucesivos intentos de restauración (el edificio fue construido a principios del siglo $\mathrm{XX}$ ) se pretendía alterar la fachada, intento que dio lugar a la formación de un petitorio ciudadano exigiendo a la alcaldía madrileña la protección del edificio. En la actualidad el conflicto de intereses continúa. Este pequeño resumen quiere llamar la atención sobre otro aspecto de la heurística warburguiana: debemos estar atento a las transformaciones estructurales en las relaciones entre lo público y lo privado y a los modos en que el arte es vehículo de esta transformación. Podríamos también analizar este proceso a partir de los trabajos de Yúdice en los que se muestra el devenir "recurso" de la cultura (acerca de este último tópico puede consultarse Navallo (2015). Como sea, nuestras prácticas artísticas ya no pueden ser pensadas sino en el interior de, y en conexión con, las nuevas formas de mecenazgo que articulan intereses económicos, prácticas de gobierno y construcción simbólica de prestigio social. 
de verlas en las paradas de buses de Madrid durante el mes de mayo del año 2018) se agrega, sugestivamente "Descubre luz donde no la hay", impreso sobre una imagen doble del ángel (una, en el propio dispositivo; otra, como fondo general del anuncio).

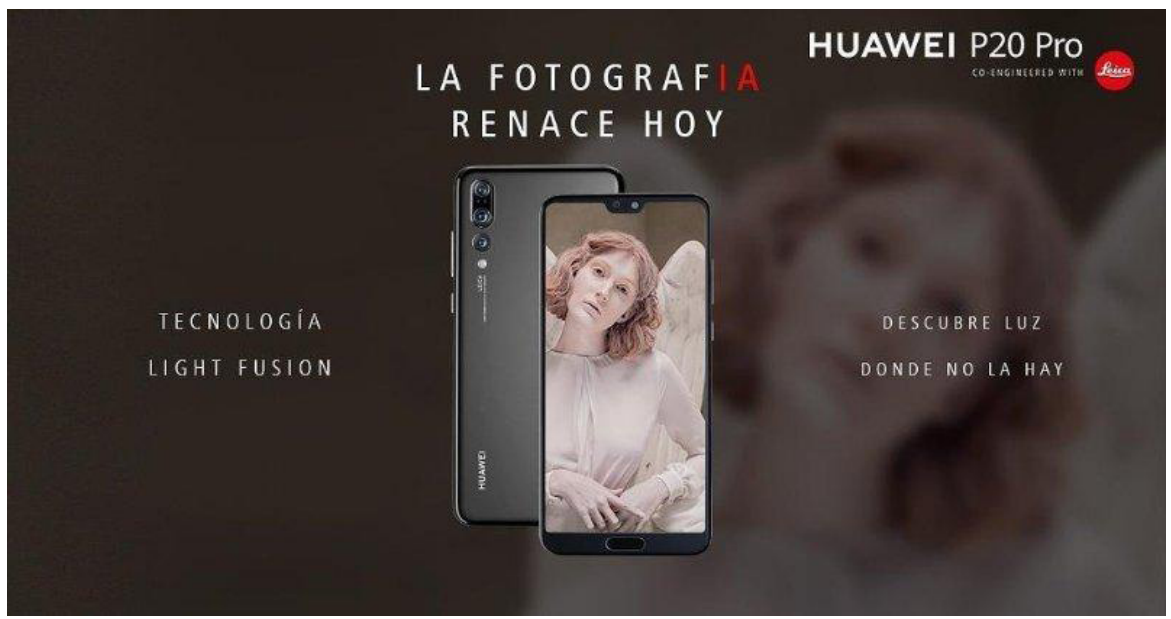

Así pues, la foto habría muerto (no se nos dice cuándo ni cómo), aparentemente por sus dificultades (dificultades materiales) para capturar la luz. El nuevo dispositivo nos promete algo nuevo, nos promete un porvenir de luz pura, nos promete una redención: la luz no será nuestro temor sino nuestra seguridad. Antes que producir imágenes, el dispositivo se encargará de producir luz. La gracia que se anuncia es la llegada de la imagen como potencia de comunicación global.

De aquel Renacimiento a este renacimiento, las imágenes han cambiado sus funciones, las han intensificado, las han invertido: el anuncio de la virgen es virginidad de la imagen. La promesa de redención es una gracia que se encarna en dispositivos. Ya no es sino la técnica quien nos liberará de las oscuridades tenebrosas de la ausencia de luz. El Anuncio de la cristiandad se transforma en anuncio de la nueva fe neoliberal. Su promesa global nos produce como consumidores, creyentes. La esperanza de la salvación vuelve, la exigencia de redención retorna: hoy que ya no es posible creer en nada: seremos salvados por la luz técnica de un dispositivo digital. Arrancar la luz donde no la hay es tornar visible aquello que quiere refugiarse en el misterio. Frente a este devenir visible del neoliberalismo la iconología warburguiana puede ser una buena herramienta para encontrar en las sombras que se pliegan en las luces algo de un último misterio.

\section{Conclusión. Combatir al fascismo}

En fin, la cultura es el efecto de las contaminaciones. La cultura, lejos de ser el territorio pacificado con que una época se refleja en la identidad de sí misma, es, en la perspectiva abierta por Warburg, un espacio de conflicto, el resultado de las migraciones, las contaminaciones, las impurezas por las que el espejo se ha roto (como diría Borges) y ya no podremos encontrar en ninguno de sus fragmentos el rostro perdido de nuestra identidad. La cultura se manifiesta como diferenciación.

Entonces ¿qué nos queda del arte cuando éste ya no es un objeto de gusto? ¿qué nos queda del arte más allá de todas sus muertes? Nos queda la vida en la obra de arte: ella exige ser interpretada. Nos queda la imagen como síntoma que interpreta la vida. Desde ahora, la pregunta que lanzamos sobre el arte es otra: se trata de indagar 
la exigencia que lo ha hecho nacer, de examinar las fuerzas que la han traído a la presencia. La imagen es expresión de esa lucha, efecto en el cual se juega nuestra existencia y por la cual la propia imagen se carga y es transporte de energías (las imágenes son, dice en otras oportunidades, "dinamogramas").

En este sentido, las imágenes que llamamos arte no tienen una función decorativa, no tienen una función "estetizante", no buscan la complacencia de nuestro placer: su rol es abrir la tensión polar como condición indispensable para que el espacio del pensamiento se pueda mantener. Hay cultura sólo cuando hay espacio del pensar, cuando hay tensión polar, cuando no se han cancelado las contradicciones que habi$\tan$ en lo que somos. La cultura está viva cuando la habitan impurezas. Al contrario, la cancelación de las contradicciones, la clausura del espacio de pensar, el fin de la tensión polar, conducen, para Warburg, al peligro del fascismo (sea el fascismo de la magia, sea el de la técnica). Es decir, a la muerte. Es lo que con la elocuencia de aquel que, con la afinidad para sentir los temblores del presente, lanza la voz de alarma ante el terremoto que su cuerpo ya presiente llegando:

Como un Prometeo o un Ícaro moderno, Franklin y los hermanos Wright, que han inventado la aeronave dirigible, son los fatídicos destructores de la noción de distancia que amenaza con reconducir este mundo al caos. El telégrafo y el teléfono destruyen el cosmos. El pensamiento mítico y simbólico, en su esfuerzo por espiritualizar la conexión entre el ser humano y el mundo circundante, hace del espacio una zona de contemplación o de pensamiento que la electricidad hace desaparecer mediante una conexión fugaz (Warburg, 2004: 66).

De ahí pues, entonces, la necesidad de persistir en el arte. O mejor, de hacer del arte una política de la vida (aunque sea de una "vida póstuma": es decir de aquello que se niega a morir, de aquello que, como los fantasmas, se instalan en la frontera indecidible entre lo que todavía vive y lo que aún no muere). Después de todo, está en juego un posible porvenir en el que el pensamiento sea una expresión de libertad, entre los monstruos que sin cesar nos interpelan y aquellos otros que sin cesar, simplemente, nos quieren aniquilar. 


\section{Q Bibliografía}

》 Arendt, H. (2003). Entre pasado y futuro. Barcelona: Península.

" Bal, M. (2016). Los tiempos trastornados. Madrid: Akal.

" Baxandall, M. (1978). Pintura y vida cotidiana en el Renacimiento. Barcelona: Gustavo Gili.

" Brea, J. L. (2005). Estudios Visuales. Epistemología de la visualidad en la era de la globalización. Madrid: Akal.

» Brea, J. L. (2010). Las tres eras de la imagen. Madrid: Akal.

»Char, R. (2002). Furor y misterio. Madrid : Visor.

»Didi Huberman, G. (1990). Avant l'image. París: Minuit.

» Didi Huberman, G. (2002) L'image survivante. Histoire de l'art et temps des fantômes selon Aby Warburg. París: Minuit.

» Foucault, M. (1992). Microfísica del poder. Madrid: La piqueta.

"García Varas, A. (2011). Filosofía de la imagen. Salamanca: Ediciones Universidad Salamanca.

» Hernández, F. (2015). Narrativa completa. Buenos Aires: Cuenco de plata.

» Michaud, P. A. (2018). Aby Warburg y la imagen en movimiento. Buenos Aires: UNA.

» Moxey, K. (2015). El tiempo de lo visual. La imagen en la historia. España: Sans Soleil.

» Navallo, L. (2015). Política cultural y procesos de formación de Estado: Pro Cultura Salta organiza los Abriles Culturales Salteños. Revista de Antropologia (USP), volumen 55,2 , 747-780.

"Navallo, L. (2019) Parcería y colaboración: hacer(se) Estado y producir arte. En C. Teixeira, A. Lobo, y L. de Lacerda Abreu (Comps). Etnografía de las Instituciones y de las Prácticas de Poder. En proceso de publicación.

» Nietzsche, F. (1983). Así habló Zaratustra. Madrid: Alianza.

"Nietzsche, F. (1994). El nacimiento de la tragedia. Madrid: Alianza

»Panofsky, E. (1972). Estudios sobre iconología. Madrid: Alianza.

» Severi, C. (2010). El sendero y la voz. Madrid: Librería Histórica

»Warburg, A. (2004). El ritual de la serpiente. México: Sexto piso.

»Warburg, A. (2005). El renacimiento del paganismo. Aportaciones a la historia cultural del Renacimiento europeo. Madrid: Alianza.

"Warburg, A. (2010). Atlas Mnemosyne. Madrid: Akal.

"Warburg, A. (2011). Mirroirs de faille, à Rome avec Giordano Bruno et Édouard Manet, 1928-1929. Dijon: Les presse du réel. 